\title{
Benign schwannoma of the radial nerve mimicking cervical radicular pain
}

\author{
Dong-seok Lee, ${ }^{1}$ Julius July ${ }^{2}$ \\ ${ }^{1}$ Imperial College School of Medicine, London, United Kingdom \\ ${ }^{2}$ Department of Neurosurgery, Siloam Hospital Lippo Village, Medical School of Pelita Harapan University, Tangerang, Indonesia
}

\begin{abstract}
Abstrak
Nyeri radikularpada lengan atas kirisering dihubungkan dengan masalah diskus servikal. Jika hasil MRI servikal tidaksesuai dengan gejala, maka kecurigaan adanya tumor saraf perifer harus dipertimbangkan. Laki-laki 54 tahun dengan presentasi nyeri radikuler pada lengan kiri, menjalani pemeriksaan untuk masalah diskus servikal, sementara hasil MRI servikalnya normal. Pada pemeriksaan fisis ditemukan Tinel's sign pada lengan atas kiri penderita. MRI fokal memperlihatkan massa berlobus pada $n$. radialis dengan diameter $1,5 \mathrm{~cm}$. Penderita menjalani operasi dan tumor dapat diangkat secara total. Pemeriksaan histopatologi memperlihatkan suatu schwannoma. (Med J Indones. 2012;21:118-20)
\end{abstract}

\begin{abstract}
Radicular pain on the arm often referred to cervical disc problems. If cervical MRI is normal, then it is necessary to rule out peripheral nerve tumor. A 54-year old man presented with radicular pain in his left arm, investigated for cervical disc problems, with normal cervical MRI. Examination shows a positive Tinel's sign on the proximal part of his left arm. Focal MRI revealed a lobulated tumor in the radial nerve $1.5 \mathrm{~cm}$ in diameter. The patient was operated and the tumor was completely removed. Histopathology confirmed the diagnosis of schwannoma. (Med J Indones. 2012;21:118-20)
\end{abstract}

Keywords: Peripheral nerve tumour, radicular pain, schwannoma, Tinel's sign

Schwannoma, also known by other names such as neurilemmoma or neurinoma refers to the tumor arising from Schwann cells, the cells that provide myelin sheath insulation for peripheral nerves. ${ }^{1}$ It is the predominant tumor of peripheral nerves. This report discusses a case of a benign schwannoma arising from the radial nerve of the patient's left arm. Only $19 \%$ of schwannomas are found in the upper extremity. ${ }^{2}$ Within the upper limb, schwannomas tend to associate with major nerves of flexor surfaces, such as the ulnar nerve; ${ }^{3}$ therefore schwannoma of the radial nerve, which supplies extensor compartment, is a rare finding. Only $7 \%$ of all peripheral schwannomas (excluding intracranial cases) arise from the radial nerve. $^{4}$

\section{CASE REPORT}

A 54 year old male shopkeeper presented with a 2 year history of spontaneous pain on his left arm. Each episode of pain lasted approximately between an hour to a day. The pain gradually became more frequent and severe; occasional night pains affected his sleep. While taking a shower, the patient noted that palpation of medial aspect of his left arm evoked a radicular tingling pain. The patient had a history of a burn on the posterior aspect of his left forearm 11 years previously. The patient is otherwise healthy.

The patient presented to other institution. Cervical magnetic resonance imaging (MRI) was taken, but it did not reveal any pathology. The patient was treated for muscle pain with pain killer and physiotherapy, but the pain persisted. Eventually he was referred to our unit.

Upon clinical examination, a palpable mass was identified on the medioposterior side of proximal part of the patient's left arm, close to the axilla. Palpation of the mass produced a radicular tingling-like pain originating from the site of palpation which travelled through the posterior aspect of arm down to the dorsum of the hand (positive of Tinel's sign). The journey of the pain corresponded to the cutaneous sensory branches of the radial nerve. Other findings of the clinical examination were unremarkable.

MRI on left upper arm demonstrated a lobulated mass lesion of a diameter of $1.5 \mathrm{~cm}$ on the radial nerve at the level of proximal part of humerus, between the medial head of the triceps muscle and the brachialis muscle. On T-1 weighted imaging with gadolinum enhancement, the mass appeared hyperintense with respect to the surrounding muscles (Figure $1 \& 2$ ).

The patient was operated under general anesthesia. A linear incision was made with the patient in supine and arm-extended position. The proximal and distal ends of the fascicle involving the tumor were identified and complete removal was performed. The tumor only involved one nerve fascicle and there were no extraneural tumors. 


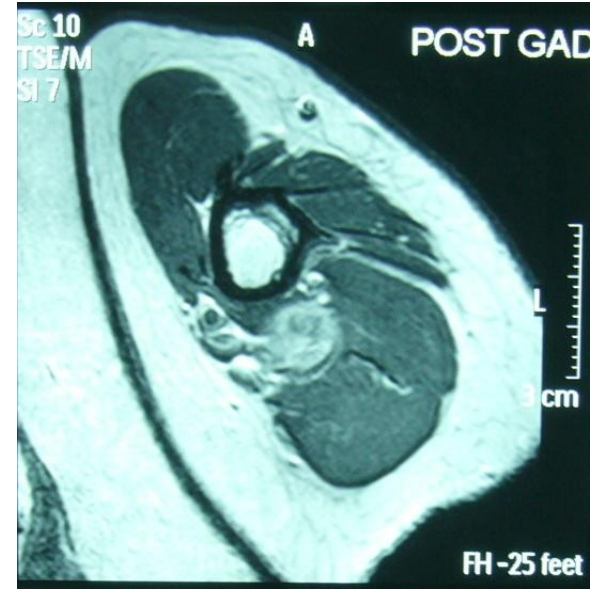

Figure 1. Hyperintense round mass is seen immediately posteriolateral to the humerus

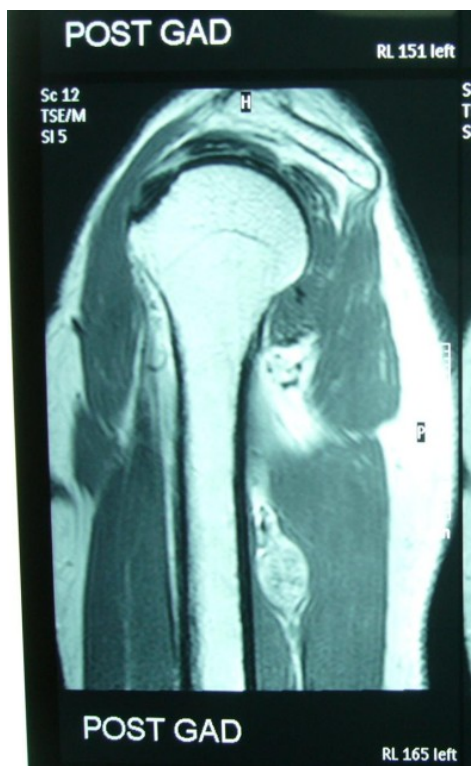

Figure 2. The hyperintense oval gray mass posterior to the humerus revealed as schwannoma hystopathologically

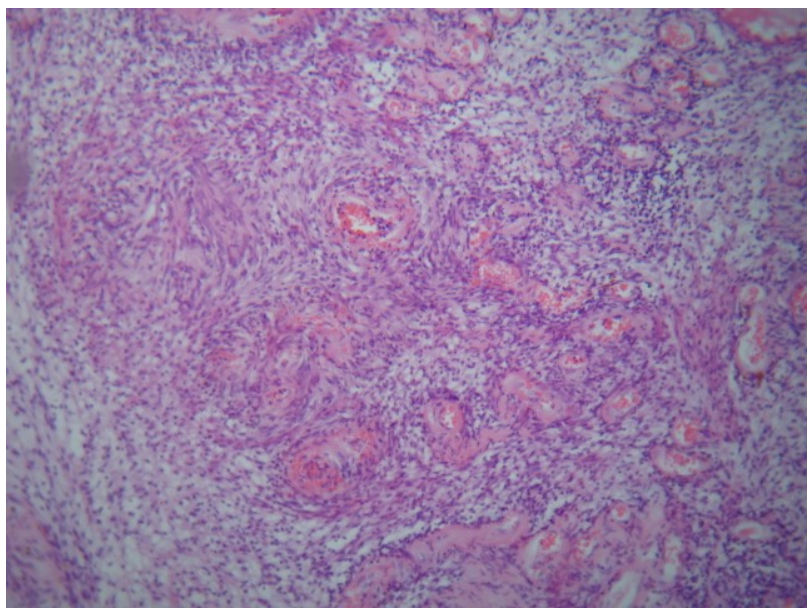

Figure 3. The histopathologic findings (Hematoxylin and eosin stain) confirmed the diagnosis as schwannoma. The tissue with loosely woven spindle cells, amidst a mucoid or serous background; blood vessels look thickened
Histopathological examination of the tumor revealed schwannoma (Figure 3). The cells of the tumor were elongated and the nuclei were mildly pleomorphic, with mostly spindle or circle shaped nuclei. The cells were in a dense palisade arrangement (Antoni type A) along with presence of loose areas (Antoni type B), which consisted of smaller sized cells with round or oval nuclei. Clusters of lipid-filled macrophages were observed.

There were no post-operative neurological symptoms, aside from temporary pain at the surgical site. The patient reported that he was free from the spontaneous/ evoked pain, 5 days after the operation.

\section{DISCUSSION}

While schwanomma is the commonest peripheral nerve tumor (PNT), it only accounts for 5\% of the soft tissue tumors of the upper extremity. ${ }^{5}$ Hence, the presence of a palpable mass in arm should not be assumed to be of nervous origin. Even when the diagnosis of a PNT is apparent, there are several types of PNTs to be suspected. According to the epidemiological study of PNTs of the upper extremity by Sandberg et al, ${ }^{6}$ thirtyfour out of 53 patients had schwannoma (64\%), while 13 had neurofibroma (25\%), while the rest were other tumors of nervous origin.

On the other hand, some of the classic symptoms of schwannoma such as radicular pain or tingling are non-specific. The findings of the schwannoma-like symptoms is unlikely to be of tumor origin. The most likely diagnosis of radicular pain of the upper limb with neurological manifestations is cervical radiculopathy, ${ }^{7}$ also known as slipped C-disc, where herniated nucleus pulposus compresses nervous tissue, hence causing neurological symptoms.

Das Gupta et $\mathrm{al}^{2}$ reported that $19 \%$ of schwannoma afflict upper limbs. The most common site of schwannoma within the upper limb is immediately distal to the elbow at $29 \%$ of total cases (12 out of 42 ), followed by the axilla, which account for $19 \%$ ( 8 out of 42 cases. $^{6}$ Schwannoma has a propensity for major nerves of flexor surface. ${ }^{3}$

Authors agree that both male and female are equally affected by schwannoma. ${ }^{4,8,9}$ However, they report a different mean age of onset of schwannoma. Donner's study of 85 patients with schwannoma (All cases of schwannomas except the inside of cranium) indicated that the mean age at presentation was 40.2 years. ${ }^{4}$ Adani's study of 24 patients with upper limb schwannoma showed that mean age of presentation was 
47 years, with a range from 22 to 77 years. ${ }^{8}$ Ozdemir's study of 14 patients with hand and wrist schwannomas indicated that the mean age at was 38.4 years with a range from 11 to $78 .{ }^{10}$ However, Abreu mentioned in his article that schwannoma most commonly affects patients of 20 30 years of age; 9 this conflicts with the previous authors' results which point towards a predilection towards middle age. However, common finding from the authors Donner, Adani, Abreu, and Ozdemir is that schwannoma is not a common tumor of either childhood or elderly., ${ }^{4,810}$ Hence, it could be deduced that the mean age at presentation ranges from young adulthood to middle age, with a general consensus towards middle age.

Treatment of schwannoma is usually surgical excision. ${ }^{9}$ Gross observation of the tumor and the position of the displaced fascicles will often reveal the underlying pathology and vital to avoid injuring the nerve during tumor removal. ${ }^{1}$

In our case, the pain is completely relief after surgery. However it's been mentioned that sometimes only partial relief of pain could be achieved even with complete removal. ${ }^{11}$ Levi et $\mathrm{al}^{11}$ showed that there was $17.2 \%$ incidence of sensory deficit, $8 \%$ for motor deficits and $3.5 \%$ for pain syndromes after surgery. Fortunately, there is no deficits after surgery in our case.

\section{REFERENCES}

1. July J, Guha A. Surgical management of benign peripheral nerve tumors. Med J Indones. 2008;7(3):163-8.

2. Das Gupta TK, Brasfield RD, Strong EW, Hajdu SI. Benign solitary schwannomas (neurilemomas). Cancer. 1969;24(2):355-66.

3. Kang HJ, Shin SJ, Kang ES. Schwannomas of the upper extremity. J Hand Surg Br. 2000;25(6):604-7.

4. Donner TR, Voorhies RM, Kline DG. Neural sheath tumors of major nerves. J Neurosurg. 1994;81(3):362-73.

5. Mackinnon S, Dellon A. Surgery of the peripheral nerve. 1st ed. New York: Thieme Medical Publishers; 1988. p. 535-40.

6. Sandberg K, Nilsson J, Soe Nielsen N, Dahlin LB. Tumours of peripheral nerves in the upper extremity: a 22-year epidemiological study. Scand J Plast Reconstr Surg Hand Surg. 2009;43(1):43-9.

7. Boutsen Y, De Coene B, Hanson P, Deltombe T, Gilliard C, Esselinckx W. Axillary schwannoma masquerading as cervical radiculopathy. Clin Rheumatol. 1999;18(2):174-6.

8. Adani R, Baccarani A, Guidi E, Tarallo L. Schwannomas of the upper extremity: diagnosis and treatment. Chir Organi Mov. 2008;92(2):85-8.

9. Abreu E, Aubert S, Wavreille G, Gheno R, Canella C, Cotten A. Peripheral tumor and tumor-like neurogenic lesions. Eur J Radiol. 2011. [Epub ahead of print].

10. Ozdemir O, Ozsoy MH, Kurt C, Coskunol E, Calli I. Schwannomas of the hand and wrist: long-term results and review of the literature. J Orthop Surg (Hong Kong). 2005;13(3):267-72.

11. Levi AD, Ross AL, Cuartas E, Qadir R, Temple HT. The surgical management of symptomatic peripheral nerve sheath tumors. Neurosurgery. 2010;66(4):833-40. 